\title{
Thermal Behavior of an Extensive Green Roof: Numerical Simulations and Experimental Investigations
}

\author{
Antonio Gagliano*, Francesco Nocera, Maurizio Detommaso and Gianpiero Evola \\ Dipartimento di Ingegneria Elettrica, Elettronica e Informatica, University of Catania, V.le Andrea \\ Doria 6, 95125 Catania (Italy) \\ Email: agagliano@dii.unict.it
}

\begin{abstract}
Green roofs produce many environmental benefits, since they can both mitigate the heat island effect and improve the energy efficiency in buildings. In particular, the Italian building stock built before Seventies (around 58\%) is characterized by a lack of thermal insulation on the roof surfaces, so the application of a green roof can be an opportunity to enhance the energy performance of those buildings.

In this study, the authors investigate the thermal behavior of a prototype of extensive green roof installed on a terraced building placed in the Mediterranean area, both through experimental measurements and dynamic simulations. The aim is to assess the feasibility and performance of this solution during the summer period. The results of the simulations indicate a strong reduction in the peak outer surface temperature if compared to the existing roof, as well a significant decrease in temperature fluctuations.

The results also allowed to assess the reliability of the simulations, if compared to experimental data. The model of the green roof proved to be sufficiently reliable, even if some minor improvements may be expected.
\end{abstract}

Keywords: Green roof, Thermal inertia, Urban heat island, Experimental measurements.

\section{INTRODUCTION}

The effects of global warming and climate change are becoming relevant for the environment and the human activities, also in the Mediterranean area. The average increase in the global air temperature by $2{ }^{\circ} \mathrm{C}$ is a critical limit by 2030 beyond, whose dangerous natural consequence must be avoided [1]. In this sense, a main factor to be considered is the high rate of energy consumption in residential and commercial buildings, which is between $30 \%$ and $50 \%$ of the worldwide total annual energy consumption, as well as the increase in the urban sprawl [2].

In particular, the optimization of existing buildings that require high electricity consumption during summer has become a key issue to decrease global energy demand [3]. This topic is of special interest in the Mediterranean basin, where a particularly sharp increase of the energy needs for cooling has been registered [4].

Since roof surface of the buildings is about $20-25 \%$ of the total urban surfaces, particular attention must be paid to these surfaces in order to reduce the air and surface temperature in urban areas [5]. Thereby new solutions for roof systems in existing or new buildings, such as green roofs, play an important role in both increasing building energy performance and in mitigating local climate phenomena typical of dense urban contexts, such as Urban Heat Island (UHI) effect [6 - 9].
Green roofs, also named "eco-roofs" or "roof gardens", are those roof systems, which have vegetation and growing medium as the outermost layer [10]. In particular, extensive green roofs are suitable for building retrofitting because they do not require any additional strengthening, thanks to their low additional loads [11].

They can provide an effective contribution to the solution of several environmental problems, both at a building and a urban scale, thanks to the vegetation effect. In addition, green roofs offer several benefits in comparison to standard roofs, because they improve storm water management $[12,13]$ as well as reduce air pollution [9, 14] and noise [15]. Furthermore, they increase the vegetable and animal biodiversity in cities $[16,17]$, and they reduce carbon dioxide to oxygen through photosynthesis process [14, 18]. Green roofs improve the duration of roofing membranes because they limit the thermal stress on the outer surfaces [19 - 21]. Finally, green roofs are often pointed at as an efficient technology to reduce the direct influence of solar radiation, together with indoor and outdoor surface temperature fluctuations [22].

Climatic conditions play an important role in the performance of green roofs. It can be noted that in the contexts where the humidity level is high during most of the year, the evapotranspiration rate and cooling capabilities are reduced [23]. 
A fundamental parameter in green roofs is the leaf area index (LAI), i.e. the total one-sided area of photosynthetic tissue per unit ground surface area [24]. Hence, the higher the LAI the denser the vegetation used in the green roof, and the higher the fraction of roof surface directly covered by at least one leaf. As a general rule, the higher the LAI, the lower the outer roof surface temperature and the cooling demand. However, a high LAI also increases the heating demand because of increased transpiration and solar shading by the foliage $[25,26]$. It was found that a high value of the LAI decreases the canopy air temperature, stabilizes its fluctuation and reduces the flux through the roof [27 - 29].

Several studies have also shown that the green roofs are characterized by peaks of outer surface temperatures ranging from $34{ }^{\circ} \mathrm{C}$ to $39{ }^{\circ} \mathrm{C}$, whereas in the same conditions standard roofs would reach peak temperatures between $50{ }^{\circ} \mathrm{C}$ and 57 ${ }^{\circ} \mathrm{C}[23,30$ - 33]. As regards the inner surface temperature, in some studies, the green roof showed a peak value of about 26 ${ }^{\circ} \mathrm{C}$; this is significantly lower than conventional roofs, whose inner surface temperature may even reach $33^{\circ} \mathrm{C}[23,28,30$, 31]. Moreover, thermal mass is an important property of the green roofs because it contributes to the absorption of large amounts of heat, while attenuating and delaying the heat transfer from the outdoors to the indoor surface. This contribution is mainly due to the surface mass of the substrate, which acts as a natural heat sink [23, 33 - 34]. This effect decreases the daily temperature fluctuations for from $37.2{ }^{\circ} \mathrm{C}$ (standard roofs) to $17^{\circ} \mathrm{C}$, while increasing the time lag of the roof from 8 hours to 10 hours [23].

This study aims at investigating the thermal behavior of a prototype of green roof installed on an existing building in Catania, a city of Southern Italy. This was done in order to assess the thermal benefits that an extensive green roof can provide on the scale in the Mediterranean Area.

The results refer to a warm week in summer; a comparison was carried out between experimental measurements and simulations for both a conventional and the green roof, thus evaluating the reliability and the limits of the numerical model implemented in the software tool DesignBuilder [35].

\section{METHODOLOGY}

This paper investigates the thermal behavior of an extensive green roof both through experimental measurements and by means of dynamic simulations.

To this aim, a prototype of an extensive green roof was installed on the building n. 13 of the Industrial Engineering Department at the University of Catania. This choice is made because on the roof of this building a weather station has already been installed, which has allowed to monitor in real time all meteorological data necessary for carrying out a correct thermal analysis of the prototype.

To this aim, a thermal monitoring system was used to measure the outdoor surface temperature of the green roof and that of the existing standard roof terrace. In this way, we were also able to evaluate the different thermal behavior between a green roof and a standard roof in Mediterranean climate. The measurements were performed in summer 2015, from the $27^{\text {th }}$ of July to the $24^{\text {th }}$ of August; in particular, the study focuses on the warmest week, occurring from the $28^{\text {th }}$ of July to the $4^{\text {th }}$ of August.

Afterwards, a model for the dynamic thermal simulation of both the prototype of green roof and the existing roof was implemented in the software tool DesignBuilder. The results of the simulation were compared to the experimental results of the survey, in order to calibrate and validate the numerical model. In addition, the simulation of the dynamic thermal behavior allowed to assess the variation of outer and inner surface temperature for both roof solutions in free running conditions (without ACs), thus calculating the Time Lag and Decrement factors.

\subsection{Experimental campaign}

The flux meter "Thermozig Plus Wireless" was used to measure the outer surface temperatures. To this aim, two thermocouples Pt100 were placed, respectively on the outer surface of the green roof substrate and on the existing roof terrace. The resolution of the sensors is $0.01{ }^{\circ} \mathrm{C}$, with an uncertainty of $0.15{ }^{\circ} \mathrm{C}$. The data were stored on a computer with a sampling time of 10 minutes, from the $27^{\text {th }}$ of July 2015 to the $24^{\text {th }}$ of August 2015.

In the same time, the weather station "Babuc - LSI Lastem" placed near the prototype was able to measure solar radiation, air temperature and humidity. The sensors have the following features:

- $\quad$ wind speed and wind direction: measurement range $=$ $0 \div 50 \mathrm{~m} \mathrm{~s}^{-1}$; threshold $=0.36 \mathrm{~m} \mathrm{~s}^{-1}$; uncertainty $=1 \%$ below $3 \mathrm{~m} \mathrm{~s}^{-1}$ and $1.5 \%$ above $3 \mathrm{~m} \mathrm{~s}^{-1}$; resolution = $0.06 \mathrm{~m} \mathrm{~s}^{-1}$;

- $\quad$ radiometer for solar irradiance: spectral response $=300$ $3000 \mathrm{~nm}$; operative temperature $=-40{ }^{\circ} \mathrm{C} /+80{ }^{\circ} \mathrm{C}$; uncertainty $= \pm 4 \mathrm{~W} \mathrm{~m}^{-2}$ (according to ISO 9060).

Figure 1 shows the weather station "Babuc LSI Lastem" and the sensors installed [36]

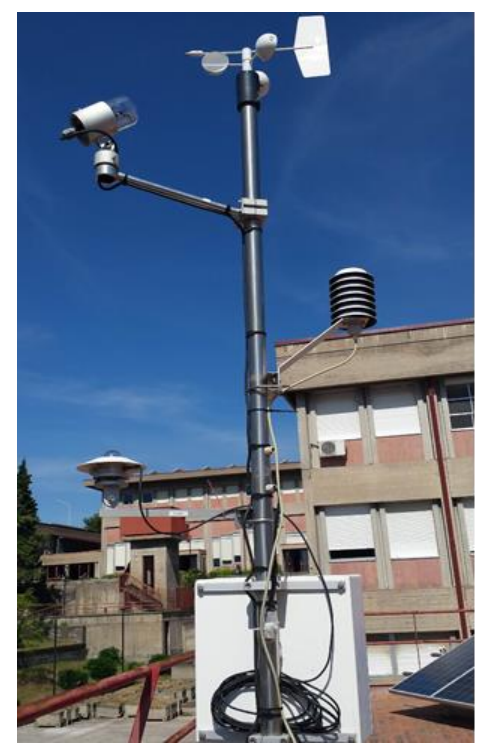

Figure 1. Babuc - LSI Lastem and its equipment

\subsection{Modelling for simulations}

After the experimental campaign, the existing roof and the prototype of green roof were modeled in the software tool DesignBuilder. DesignBuilder is a three-dimensional modelling and energy simulation tool, which is able to perform dynamic thermal simulations. The simulation engine EnergyPlus [37], integrated within DesignBuilder, runs all the necessary calculations related to the building energy 
model (BEM) and reports the results within the DesignBuilder interface.

In the simulations, the two roof solutions have been implemented according to their actual stratigraphy, described in Section 3. In particular, the green roof was modeled adding to the existing roof the stratigraphy of the prototype.

For simulation purposes, the roofs were applied to two sample rooms that measure $5 \mathrm{~m} \times 5 \mathrm{~m}$ in width, and $3 \mathrm{~m}$ in height. Since the aim of the simulations is to investigate the roof performance in terms of surface temperatures, while no information is collected about the indoor conditions, considerable simplifications were introduced to describe the test room. In particular, the room is considered not occupied, it does not contain any internal gain and no space heating or cooling systems are available. Moreover, the external walls and the ground floor were assumed as being adiabatic, so that thermal fluxes are only exchanged through the roof.

The solution method for the temperature distribution in the walls is the Conduction Transfer Function. The time step used for simulations is one minute. As concerns the calculation of the convective heat transfer coefficients for the roof surfaces, which is particularly relevant in this study, the TARP model and the ClearRoof model were selected, respectively for the inner and the outer surface.

All weather data used in the weather file correspond to those actually measured by the weather station. This allows to test more precisely the accuracy and sensitivity of the model. Actually, the weather file in DesignBuilder does not contain information about precipitation. However, no rainfall occurred during the measurement campaign described in this paper.

\subsection{Thermal inertia parameters}

It is well known that the energy performance of buildings depends strongly on the thermal inertia of the building envelope components. In particular, high thermal mass and heat capacity contribute to attenuate and delay the peaks in the cooling load [38].

The time lag (TL) and the decrement factor (DF) are the two parameters widely used for characterizing the thermal inertia and heat storage capability of buildings. The Time lag (TL) is measured by the difference between the times when the maximum outer and inner surface temperatures occur:

$$
\mathrm{TL}=\tau_{\mathrm{T}_{\mathrm{so}, \max }}-\tau_{\mathrm{T}_{\mathrm{si}, \max }}
$$

On the other hand, the decrement factor (DF) can be defined as the ratio of the amplitude of the inner surface temperature fluctuations to the amplitude of the outer surface temperature fluctuations:

$$
\mathrm{DF}=\frac{\mathrm{T}_{\text {si,max }}-\mathrm{T}_{\text {si,min }}}{\mathrm{T}_{\text {so,max }}-\mathrm{T}_{\text {so,min }}}
$$

In this work, these two indexes are used to characterize the thermal behavior of the prototype of green roof compared to the standard roof, and to evaluate the beneficial effect for improving the indoor wellbeing conditions.

\section{CASE STUDY}

The prototype of an extensive green roof was installed on the existing roof of the building n.13 of the Industrial Engineering Department at the University of Catania (lat. $37^{\circ} 30^{\prime} \mathrm{N}$, long. $15^{\circ} 04^{\prime} \mathrm{E}$ ). The city, located in Southern Italy, is characterized by 833 heating degree-days in winter and 2674 cooling degree-days in summer, defined relative to a base outdoor temperature of $12^{\circ} \mathrm{C}$ and $24^{\circ} \mathrm{C}$, respectively.

Generally, this city has a mild climate with hot, dry summers and moderately cool, wet winters. In summer months, the average outdoor temperature ranges from $23{ }^{\circ} \mathrm{C}$ to $35^{\circ} \mathrm{C}$, with peaks of $39{ }^{\circ} \mathrm{C}$ when the hot winds blow from North Africa. In winter, the outdoor temperature varies from $5{ }^{\circ} \mathrm{C}$ to $15^{\circ} \mathrm{C}$, while in spring and autumn the climate is very mild and the temperatures vary from $10{ }^{\circ} \mathrm{C}$ to $28^{\circ} \mathrm{C}$.

The meteorological data recorded by the weather station from the $27^{\text {th }}$ of July to the $27^{\text {th }}$ of August 2015 point out that a typical summer daytime is also characterized by high solar irradiance. On average, the solar irradiance on the horizontal surface attains around $800 \mathrm{~W} \mathrm{~m}^{-2}$, associated with an average outdoor temperature as high $28.8^{\circ} \mathrm{C}$, relative humidity of 60 $\%$ and wind speed of $3.7 \mathrm{~m} \mathrm{~s}^{-1}$. No rainfall occurred during the measurement campaign described in this paper.

\subsection{Existing roof}

The prototype realized for experimental measurements was placed on the existing roof terrace. The roof is built in reinforced concrete with a thickness of $60 \mathrm{~cm}$. The outer surface of the roof is coated by a pavement of clay shingles, characterized by solar absorptance $\alpha=0.60$ and thermal emissivity $\varepsilon=0.90$. All the layers of the roof and their thermo-physical properties are reported in Table 1; here, a thermal resistance $\mathrm{R}=0.23 \mathrm{~m}^{2} \mathrm{~K} \mathrm{~W}^{-1}$ is assumed for the unventilated air gap, as suggested by UNI EN ISO 6946:2008 in case of descending thermal flow. Overall, the roof terrace has a surface mass $\mathrm{SM}=516 \mathrm{~kg} \mathrm{~m}^{-2}$, with a $\mathrm{U}$-value $=1.42$ $\mathrm{W} \mathrm{m} \mathrm{K}^{-1}$ and a thermal resistance $\mathrm{R}=0.70 \mathrm{~m}^{2} \mathrm{~K} \mathrm{~W}^{-1}$.

Table 1. Stratigraphy and thermal properties of roof terrace

\begin{tabular}{lllll}
\hline Layers & $\begin{array}{l}\mathrm{s} \\
(\mathrm{m})\end{array}$ & $\begin{array}{l}\lambda \\
\left(\mathrm{W} \mathrm{m}^{-1} \mathrm{~K}^{-1}\right)\end{array}$ & $\begin{array}{l}\rho \\
\left(\mathrm{kg} \mathrm{m}^{-3}\right)\end{array}$ & $\begin{array}{l}\mathrm{C}_{\mathrm{p}} \\
\left(\mathrm{J} \mathrm{kg}^{-1} \mathrm{~K}^{-1}\right)\end{array}$ \\
\hline Clay shingles & 0.01 & 0.72 & 1,800 & 840 \\
\hline Mortar cement & 0.04 & 1.40 & 1,500 & 2,000 \\
\hline $\begin{array}{l}\text { Polyester } \\
\text { membrane }\end{array}$ & 0.01 & 0.16 & 1,120 & 1,460 \\
\hline $\begin{array}{l}\text { Light cement } \\
\text { screed }\end{array}$ & 0.10 & 1.35 & 1,800 & 1,000 \\
\hline $\begin{array}{l}\text { Concrete } \\
\text { medium density }\end{array}$ & 0.03 & 1.35 & 1,800 & 1,000 \\
\hline Reinforced base & 0.06 & 1.40 & 2,000 & 840 \\
\hline $\begin{array}{l}\text { Prefabricated } \\
\text { slab }\end{array}$ & 0.06 & 1.16 & 2,000 & 880 \\
\hline Air gap & 0.30 & - & - & - \\
\hline Ceiling & 0.02 & 0.21 & 900 & 840 \\
\hline
\end{tabular}

\subsection{Prototype of green roof}

The prototype is composed by two boxes of $1 \times 1 \mathrm{~m}$ with a height of $25 \mathrm{~cm}$. It stratigraphy includes a drainage layer, a filter layer, growing medium and a vegetation layer. Figure 2 reports some pictures of the prototype. In particular, Figure 
2.b corresponds to the situation during the warmest week; here, it is possible to observe that all plants were considerably grown and the foliage was very thick.

The substrate is a porous soil composed by a mixture of peat, pumice, mineral aggregates and other soil granules. Evergreen and succulent plants, which require minimum maintenance, constitute the vegetation layer. In particular, we have adopted evergreen plants named "Felicia Amelloides" and "Lantana Camara", and the succulent typology "Lampranthus". These plants grow across the ground rather that upwards, thus offering good coverage and protection to the roof membrane. Moreover, they are capable to store water in their leaves making them highly resistant to drought.

During the period of monitoring of the prototype, the plants had an average measured height of $35 \mathrm{~cm}$. The prototype was finally equipped with a drip irrigation system which was switched on every day of the week from 09:00 to 09:10 in the morning and from 16:00 to $16: 10$ in the afternoon. The same schedule of irrigation was set in the simulations; the water flow rate used for irrigation purposes is assessed as $20 \mathrm{~mm}$ per hour. The same schedule of irrigation was set in the simulations; the water flow rate used for irrigation purposes is assessed as $20 \mathrm{~mm}$ per hour.

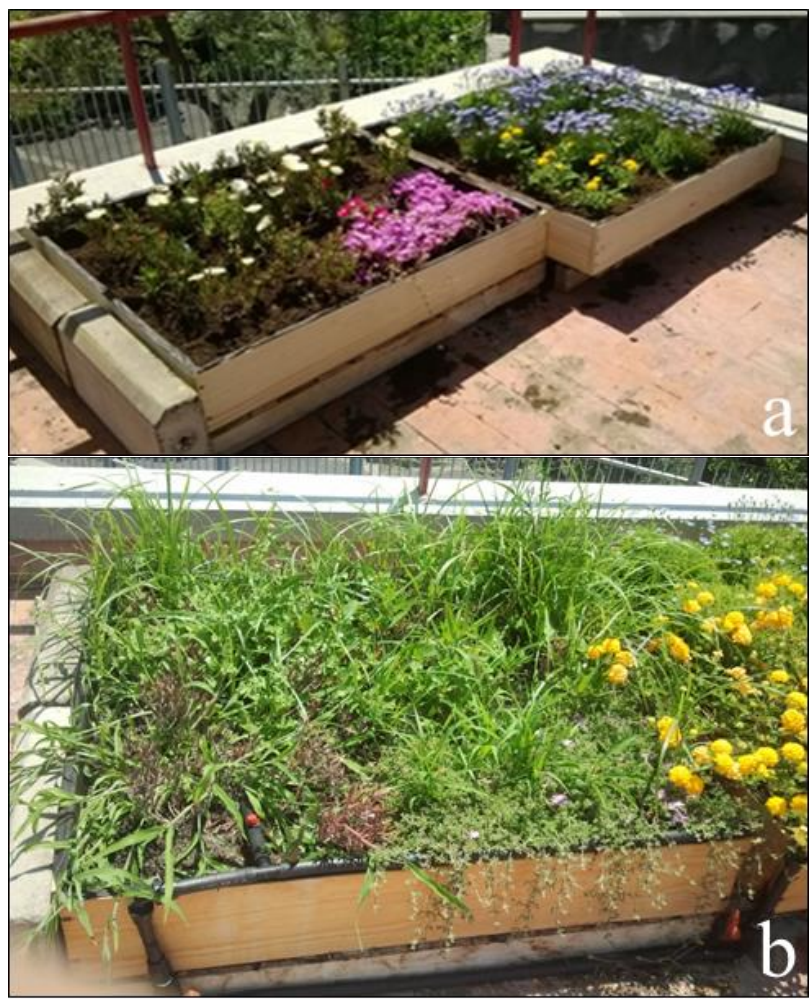

Figure 2. Prototype of green roof, a) Configuration at the installation time, b) Situation during the warmest week

\subsection{Main properties of the green roof}

Figure 3 and Table 2 show the stratigraphy of the prototype of the extensive green roof installed on the existing terrace. According to these data, the extensive green roof has a $\mathrm{U}$-value $=1.03 \mathrm{~W} \mathrm{~m}^{-2} \mathrm{~K}^{-1}$, a thermal resistance $\mathrm{R}=0.97 \mathrm{~m}^{2}$ $\mathrm{K} \mathrm{W}^{-1}$ and a surface mass $\mathrm{SM}=744 \mathrm{~kg} \mathrm{~m}^{-2}$. These data do not include the vegetation layer.

The substrate is a thin layer $(15 \mathrm{~cm})$ of cultivated peat soil with $91 \%$ porosity, whose initial and residual moisture content is set to 0.50 and $0.08 \mathrm{~m}^{-3} \cdot \mathrm{m}^{-3}$, respectively [39]. The thermo-physical properties of the substrate layer are shown in Table 3. The geometric data and thermo-physical properties of the foliage were estimated through an accurate literature survey, and are reported in Table $4[23,40]$.

In particular, the leaf area index has been set to LAI $=5$, which is a quite high value for extensive roofs. However, this choice is justified by the intense growth of the plants during the period of measurement, when the substrate was almost entirely covered by the foliage.

The high saturation moisture content of the terrain $\left(\theta_{\text {sat }}=\right.$ $\left.0.70 \mathrm{~m}^{3} \mathrm{~m}^{-3}\right)$ is typical of a very porous terrain like the one adopted in the prototype [39]. Moreover, the choice of a relatively high initial moisture content $\left(\theta_{\text {sat }}=0.50 \mathrm{~m}^{-3} \mathrm{~m}^{-3}\right)$ is coherent with the fact that the terrain had been regularly irrigated in the days before the measurement campaign.

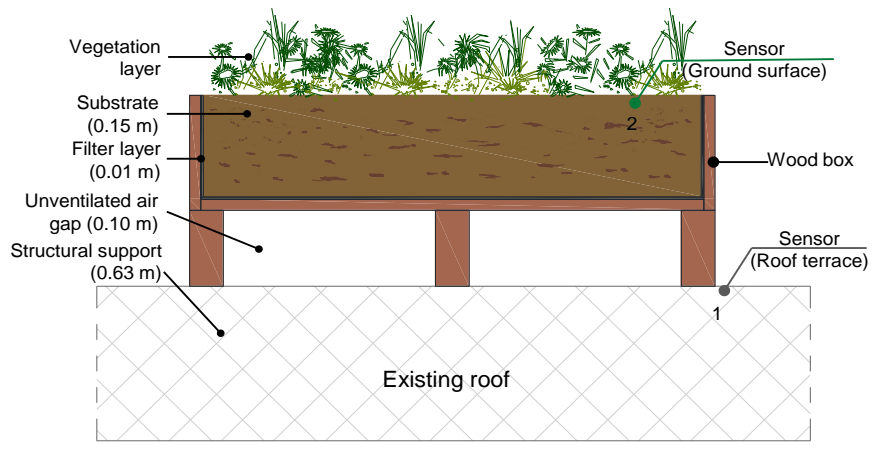

Figure 3. Stratigraphy of the prototype of green roof.

Table 2. Thermal properties of the layers of the prototype.

\begin{tabular}{lllll}
\hline Layers & $\begin{array}{l}\lambda \\
\left(\mathrm{W} \mathrm{m}^{-1} \mathrm{~K}^{-1}\right)\end{array}$ & $\begin{array}{l}\rho \\
\left(\mathrm{kg} \mathrm{m}^{-3}\right)\end{array}$ & $\begin{array}{l}\mathrm{C}_{\mathrm{p}} \\
\left(\mathrm{J} \mathrm{kg}^{-1} \mathrm{~K}^{-1}\right)\end{array}$ & $\begin{array}{l}\mathrm{R} \\
\left(\mathrm{m}^{2} \mathrm{~K} \mathrm{~W}^{-1}\right)\end{array}$ \\
\hline Vegetation & - & - & - & - \\
\hline Substrate & 1.00 & 1,400 & 1,500 & 0.15 \\
\hline Filter & 0.22 & 1,800 & 910 & 0.04 \\
\hline Air gap & 0.70 & - & - & 0.12 \\
\hline
\end{tabular}

Table 3. Thermophysical properties of the substrate layer.

\begin{tabular}{llll}
\hline Thermal conductivity & $\lambda$ & 1.00 & $\mathrm{~W} \mathrm{~m}^{-1} \mathrm{~K}^{-1}$ \\
\hline Density & $\rho_{\mathrm{g}}$ & 1,400 & $\mathrm{~kg} \mathrm{~m}^{-3}$ \\
\hline Specific heat & $\mathrm{C}_{\mathrm{p}}$ & 1,500 & $\mathrm{~J} \mathrm{~kg}^{-1} \mathrm{~K}^{-1}$ \\
\hline Emissivity & $\varepsilon_{\mathrm{g}}$ & 0.90 & - \\
\hline Absorptance & $\alpha_{\mathrm{g}}$ & 0.60 & - \\
\hline Initial moisture content & $\theta_{\text {in }}$ & 0.50 & $\mathrm{~m}^{3} \mathrm{~m}^{-3}$ \\
\hline $\begin{array}{l}\text { Saturation moisture } \\
\text { content }\end{array}$ & $\theta_{\text {sat }}$ & 0.70 & $\mathrm{~m}^{3} \mathrm{~m}^{-3}$ \\
\hline
\end{tabular}

Table 4. Thermophysical properties of the vegetation layer.

\begin{tabular}{llll}
\hline Height of the plants & $\mathrm{H}$ & 0.35 & $\mathrm{~m}$ \\
\hline Leaf area index & LAI & 5 & $\mathrm{~m}^{2} \mathrm{~m}^{-2}$ \\
\hline Reflectivity & $\mathrm{r}_{\mathrm{f}}$ & 0.25 & - \\
\hline Absorptance & $\alpha_{\mathrm{f}}$ & 0.60 & - \\
\hline Transmissivity & $\mathrm{t}_{\mathrm{f}}$ & 0.15 & - \\
\hline Emissivity & $\varepsilon_{\mathrm{f}}$ & 0.95 & - \\
\hline Minimum stomatal resistance & $\mathrm{r}_{\mathrm{s}}$ & 180 & $\mathrm{~s} \mathrm{~m}^{-1}$ \\
\hline
\end{tabular}




\section{EXPERIMENTAL MEASUREMENTS}

The measurements were carried-out during a summer period in 2015 (from the $27^{\text {th }}$ of July to the $24^{\text {th }}$ of August).

Figure 4 depicts the hourly profiles of solar irradiance on the horizontal plane (I) and outdoor air temperature $\left(\mathrm{T}_{\mathrm{o}}\right)$ as measured from the $28^{\text {th }}$ of July to the $4^{\text {th }}$ of August, which is the warmest week during the survey.

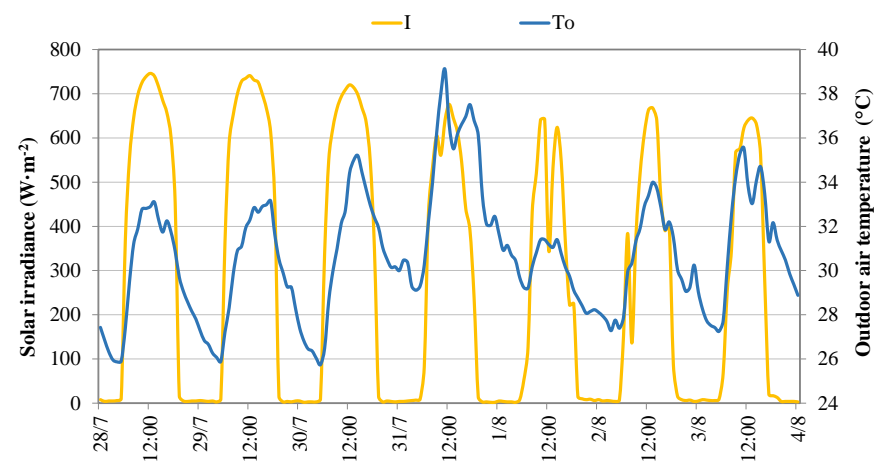

Figure 4. Profiles of solar radiation (I) and outdoor air temperature $\left(\mathrm{T}_{\mathrm{o}}\right)$ form $28^{\text {th }}$ July to $4^{\text {th }}$ August.

It was found that the peak of the outdoor temperature is in phase with the peak value of daily irradiation. During the week, the maximum values were respectively $\mathrm{I}=746 \mathrm{Wm}^{-2}$ and $\mathrm{T}_{\mathrm{o}}=39.1{ }^{\circ} \mathrm{C}$. The minimum value for $\mathrm{T}_{\mathrm{o}}$ was $25.74{ }^{\circ} \mathrm{C}$, which occurred at 05:00 a.m.

On the other hand, Figure 5 shows the profile for the outer surface temperature measured both on the prototype of green roof (GR) and on the existing roof (TR).

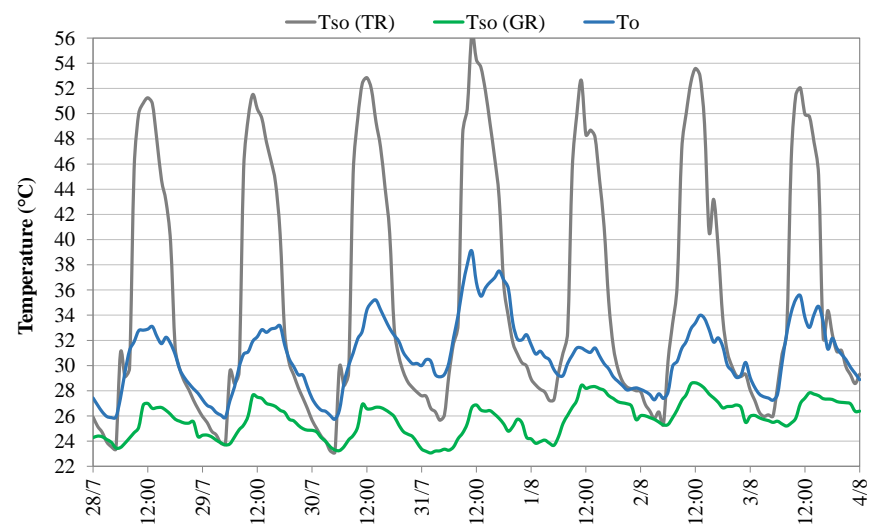

Figure 5. Trend for the outer surface temperature of green and existing roof ( $28^{\text {th }}$ July to $4^{\text {th }}$ August 2015).

As expected, the green roof allows a strong reduction in the peak outer surface temperature. Indeed, the peak is $\mathrm{T}_{\mathrm{so}}=$ $56.3^{\circ} \mathrm{C}$ for the existing roof terrace, whereas the max value for the green roof is $28.6{ }^{\circ} \mathrm{C}$, with a gap of $28.7{ }^{\circ} \mathrm{C}$. Moreover, during the survey the surface temperature of the green roof is always lower than the surface temperature of the existing roof terrace. This is mainly due to the impact of vegetation layer, which provides a suitable microclimate and reduces the heat flux by direct radiation.

The minimum values of outdoor surface temperature for both existing and green roof are almost coincident all days of the examined week, with the only exception of the $31^{\text {st }}$ of
July and the $1^{\text {st }}$ of August, when a difference of $3{ }^{\circ} \mathrm{C}$ at night was recorded.

The analysis of the experimental results also highlights that the green roof significantly reduces the daily swing in the surface temperature. Indeed, the maximum daily variation of the green roof was $5.6{ }^{\circ} \mathrm{C}$, whereas for the existing roof this was $33.2^{\circ} \mathrm{C}$.

In addition, we have calculated the cumulated percentage of time during which the outer surface temperature of the roof is below a certain value. The results are reported in Figure 6.

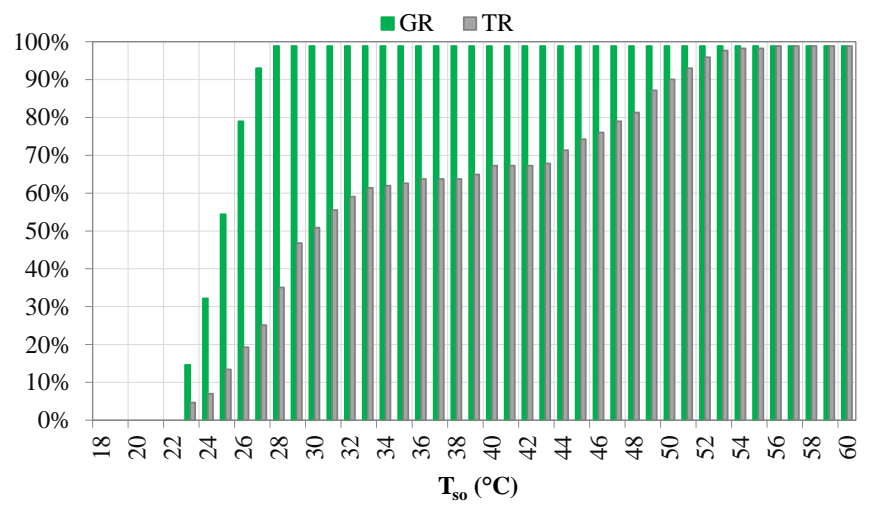

Figure 6. Cumulated frequency distribution of the measured outer surface temperature ( $28^{\text {th }} \mathrm{July}-4^{\text {th }}$ August).

Here, one can observe that the outer surface temperature is always below $28{ }^{\circ} \mathrm{C}$ for the green roof, whereas for the existing roof it has exceeded this threshold for the $40 \%$ of time, and it has reached $54{ }^{\circ} \mathrm{C}$.

\section{MEASUREMENTS VS. SIMULATIONS}

The evaluation of the outer surface temperature for the existing roof and the green roof prototype was also performed through dynamic simulations with DesignBuilder. The simulations refer to the same survey period, and use as an input the same weather data registered by the monitoring station. For green roofs, the result refers to the soil surface temperature, which is coherent with the experimental acquisitions.

The results of the simulations confirm the better thermal behavior of the green roof. Moreover, as illustrated by Figure 7 and Figure 8, the comparison between the experimental measurements and the simulated results is satisfying. Indeed, for the existing roof terrace there occurs an almost perfect coincidence of the trends of outer surface temperature obtained by the simulations and experimental survey (Figure $7)$. On the other hand, for the green roof some differences occurs, as reported in Figure 8. In particular, the temperatures calculated through simulations are around $2-3{ }^{\circ} \mathrm{C}$ lower during the night, if compared with those measured. This could be due to an overestimation of the low long-wave radiation exchange with the sky because of low sky temperatures. Moreover, an inaccurate estimation of the evapotranspiration phenomena may encourage the cooling of the green roof surface.

On the contrary, the simulated peak surface temperatures exceed the experimental values by less than $2^{\circ} \mathrm{C}$. Overall, the temperature trend is well represented, as is the response of the roof to fluctuations of the outdoor conditions. 
These results comply with the study of Sailor [40], who found out that the absolute percentage difference between the measured data and simulated data is within $10 \%$.

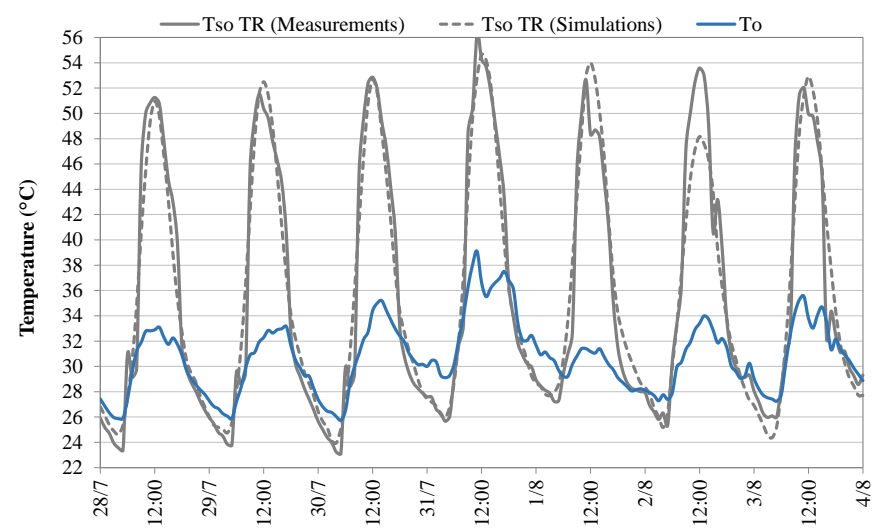

Figure 7. Outer surface temperatures: comparison between measurements and simulations (existing roof)

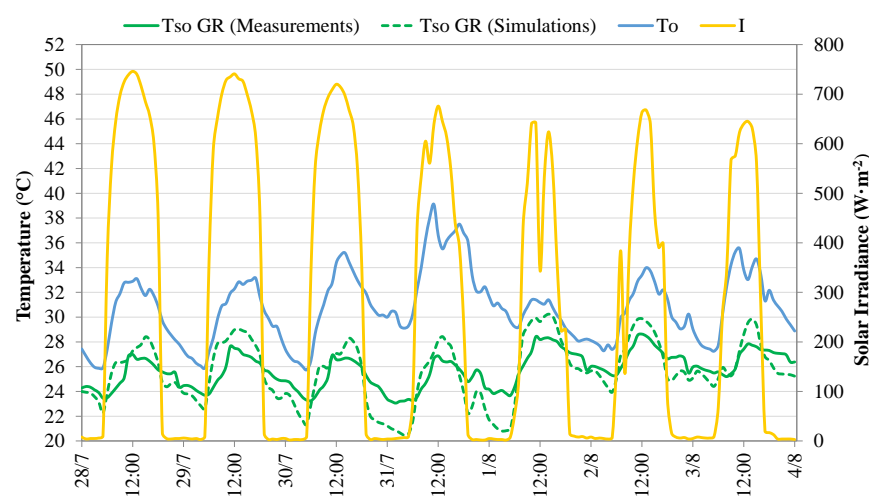

Figure 8. Outer surface temperatures: comparison between measurements and simulations (green roof)

\section{DYNAMIC THERMAL PROPERTIES}

With the aim of analyzing the influence of the green roof on the dynamic thermal behavior of the building, the results of the simulations were used to determine the Time Lag (TL) and the Decrement Factor (DF) of both roof solutions.

To this aim, the hourly profiles of the outer and inner surface temperatures calculated by DesignBuilder in free running conditions during the warmest day ( $1^{\text {st }}$ of August $)$ are reported in Figure 9. The inner temperatures may not be very accurate because of the adiabatic wall assumption made in the simulations.

The existing roof shows a wide fluctuation of its surface temperature: the outer temperature attains its peak value $\left(\mathrm{T}_{\text {so,max }}=54{ }^{\circ} \mathrm{C}\right)$ in phase with the maximum daily value of the solar radiation, that is to say at around 13:00. On the other hand, the inner surface temperature keeps always above $\mathrm{T}_{\mathrm{si} \text {,min }}=34.3{ }^{\circ} \mathrm{C}$; the peak inner surface temperature $\left(\mathrm{T}_{\mathrm{si}, \max }=\right.$ $36.2{ }^{\circ} \mathrm{C}$ ) occurs at 21:00. Thereby, the TL for the traditional roof is about 8 hours, while $\mathrm{DF}=0.072$. Instead, the green roof shows lower fluctuations of the surface temperature if compared to the existing roof, with a maximum value $\mathrm{T}_{\mathrm{so} \text {, max }}$ $=29{ }^{\circ} \mathrm{C}$ for the outer surface at around 13:00. The inner surface temperature shows a very smooth profile, between a minimum $\mathrm{T}_{\mathrm{si}, \min }=25^{\circ} \mathrm{C}$ and a maximum $\mathrm{T}_{\mathrm{si}, \max }=25.9{ }^{\circ} \mathrm{C}$, which occurs at 23:00. Hence, $\mathrm{TL}=10 \mathrm{~h}$ and $\mathrm{DF}=0.136$. The main dynamic parameters obtained by hourly simulations for both roofs are reported in Table 5 .

These results are close to what reported in other studies $[24,31,32]$, where green roofs show peak outer surface temperatures between $32{ }^{\circ} \mathrm{C}$ and $39^{\circ} \mathrm{C}$, while the peaks for standard roofs were between $50{ }^{\circ} \mathrm{C}$ and $57^{\circ} \mathrm{C}$.

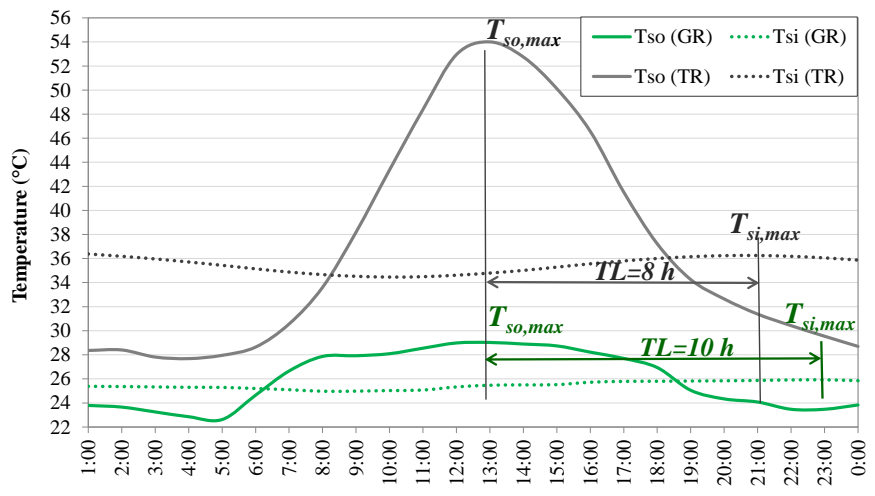

Figure 9. Simulated hourly profiles of inner and outer surface temperature for green (GR) and existing roof (TR).

Table 5. Dynamic parameters for existing and green roof.

\begin{tabular}{lllllll}
\hline Roof & $\mathrm{T}_{\text {so } \text { max }}$ & $\mathrm{T}_{\text {so,min }}$ & $\mathrm{T}_{\text {si,max }}$ & $\mathrm{T}_{\text {so,max }}$ & $\mathrm{TL}$ & $\mathrm{DF}$ \\
\hline $\mathrm{TR}$ & $54.0^{\circ} \mathrm{C}$ & $27.7^{\circ} \mathrm{C}$ & $36.2^{\circ} \mathrm{C}$ & $34.3^{\circ} \mathrm{C}$ & $8 \mathrm{~h}$ & 0.072 \\
\hline $\mathrm{GR}$ & $29.0^{\circ} \mathrm{C}$ & $22.4^{\circ} \mathrm{C}$ & $25.9^{\circ} \mathrm{C}$ & $25.0^{\circ} \mathrm{C}$ & $10 \mathrm{~h}$ & 0.136
\end{tabular}

However, a controversial message seems to emerge from the results of Table 5. Indeed, the green roof shows a better TL than the traditional roof, but - on the contrary - the more favorable value of the decrement factor DF pertains to the traditional roof. Anyway, it is undeniable that the soil layer in the green roof raises the surface mass, thus contributing to increase the inertial capacity of the roof.

Here, this ambiguity can be justified as follows. The definition of DF provided in Eq. (2) is intended for comparing the thermal response of two different envelope solutions that are subject to the same outer forcing condition, i.e. to the same fluctuation of the outer surface temperatures. In this case, however, the vegetation layer in the green roof contributes to attenuate the amplitude of the outer surface temperature fluctuation (from $26.3^{\circ} \mathrm{C}$ to $5.6^{\circ} \mathrm{C}$ ). Hence, even if the amplitude of the inner surface temperature fluctuation is still higher for the traditional roof $\left(1.9^{\circ} \mathrm{C}\right)$ than for the green roof $\left(0.9^{\circ} \mathrm{C}\right)$, the $\mathrm{DF}$ does not correctly reflect it.

In this case, the authors propose an alternative formulation for the decrement factor, based on the concept of sol-air temperature $\mathrm{T}_{\text {as }}$ :

$\mathrm{DF}^{\prime}=\frac{\mathrm{T}_{\mathrm{si}, \max }-\mathrm{T}_{\mathrm{si}, \min }}{\mathrm{T}_{\mathrm{as}, \max }-\mathrm{T}_{\mathrm{as}, \min }}$

The sol-air temperature must be calculated through Eq. (4) with reference to a standard solar absorptance, that can be set as high as for the traditional roof $(\alpha=0.6)$. The outer surface heat transfer coefficient is $\mathrm{h}_{\mathrm{o}}=25 \mathrm{~W} \mathrm{~m}^{-2} \mathrm{~K}^{-1}$.

$\mathrm{T}_{\mathrm{as}}=\mathrm{T}_{\mathrm{o}}+\frac{\alpha \cdot \mathrm{I}}{\mathrm{h}_{\mathrm{o}}}$ 
The application of Eq. (4) to the weather data registered during the warmest day ( $1^{\text {st }}$ of August) provides the following results: $\mathrm{T}_{\mathrm{as}, \max }=46.8{ }^{\circ} \mathrm{C}$ and $\mathrm{T}_{\mathrm{as}, \min }=28.1{ }^{\circ} \mathrm{C}$. Hence, Eq. (3) returns $\mathrm{DF}^{\prime}=0.101$ for the traditional roof and $\mathrm{DF}^{\prime}=0.048$ for the green roof.

Now, the ratio between the decrement factors is almost exactly $2: 1$, in favor of the green roof. This result perfectly reflects the ratio of the inner surface temperature fluctuations; consequently, the definition of DF provided by Eq. (3) seems suitable to describe in brief the difference inertial behaviour of the two roof solutions.

\section{CONCLUSIONS}

In this study, the thermal behavior of an extensive green roof is investigated through both experimental measurements and dynamic simulations. The aim of the work is to evaluate the reliability and performance of the proposed extensive green roof realized on an existing building in Mediterranean climate. The study also aimed to assess the reliability and sensitivity of the numerical model implemented on a commercial software for dynamic simulations.

The results highlight that the green roof has a good thermal behavior in summer. In fact, the prototype has significantly contributed to reduce the peak outdoor surface temperature from $56.3{ }^{\circ} \mathrm{C}$ to $28.6{ }^{\circ} \mathrm{C}$. Moreover, it delays the peak inner surface temperature more than obtained with the existing roof terrace.

The green roof allows controlling the outdoor heat wave better than a standard roof, reducing the daily temperature fluctuations from a value of $33.2{ }^{\circ} \mathrm{C}$ (standard roof) to $5.6{ }^{\circ} \mathrm{C}$ (green roof). The reduction in the outer surface temperature is mainly due to the effect of vegetation layer, because the foliage realizes a microclimate that is just slightly affected by the action of the direct solar radiation. Indeed, the canopy layer acts like a screen that blocks solar gains and improves the performance of the thermal mass.

Overall, the comparison between experimental data and simulations indicates a good correspondence in terms of outer surface temperature for the existing roof terrace, but a slight discrepancy occurs the green roof. Here, the peak outer surface temperature are overestimated by less than $2{ }^{\circ} \mathrm{C}$, while the minimum temperature at night are underestimated by around $3{ }^{\circ} \mathrm{C}$

In this sense, further studies are necessary to improve the reliability of the model, so as to allow assessing with higher accuracy the energy performance of green roofs by varying the climatic conditions, the typology of substrate, the drainage and vegetation layer.

\section{REFERENCES}

[1] IEA, World Energy Outlook 2008-2009, International Energy Agency, Geneva, 2009.

[2] M. J. Holmes and N. J. Hacker, "Climate change, thermal comfort and energy: meeting the design challenges of the $21^{\text {st }}$ Century," Energ Buildings, vol. 39, pp. 177-189, 2007. DOI 10.1016/j.enbuild.2007.02.009.

[3] ROOFSOL: Roof Solutions of natural cooling. Contract No. JOR3CT960074, Commission of the
European Communities. DG XII Science, Research and Development.

[4] W. Ishida, Overview of the world air-conditioning market. Presented at the Appliances Magazine.com [online], 2007. Available: http://www.appliancemagazine.com/editorial.php?artic le $=1812$ \&zone $=207 \&$ first $=1$.

[5] H. Akbari, S. L. Rose and H. Taha, "Analyzing the land cover of an urban environment using highresolution orthophotos," Landscape Urban Plan, vol. 63, pp. 1-14, 2003. DOI: 10.1016/S01692046(02)00165-2.

[6] A. Synnefa, A. Dandou, M. Santamouris, M. Tombrou and N. Soulakellis, "On the use of cool materials as a heat island mitigation strategy," J Appl Meteorol Clim, vol. 47, pp. 2846-2856, 2008. DOI: 10.1175/2008JAMC1830.1.

[7] H. Akbari and S. Konopacki, "Calculating energysaving potentials of heat-island reduction strategies," Energ Policy, vol. 33, pp. 721-756, 2005. DOI: 10.1016/j.enpol.2003.10.001

[8] H. Akbari, S. Menon and A. Rosenfeld, "Global cooling: increasing world-wide urban albedos to offset $\mathrm{CO}_{2}$," Climatic Change, vol. 94, pp. 275-286, 2009. DOI: $10.10007 / \mathrm{s} 10584-008-9515-9$.

[9] Q. Yang, P. Y. Gong, "Quantifying air pollution removal by green roofs in Chicago," Atmos Environ, vol. 42, no. 31, pp. 7266-7273, 2008. DOI: 10.1016/j.atmosenv.2008.07.003.

[10] K. Niachou, K. Papakonstantinou, A. Santamouris, A. Tsagroussoulis and G. Mihalakakou, "Analysis of the green roof thermal properties and investigations of its energy performance," Energ Buildings, vol. 33, pp. 719-729, 2001. DOI: 10.1016/S0378-7788(01)000627.

[11] H. F. Castleton, V. Stovin, S. B. M. Beck and J. B. Davison, "Green roofs: building energy savings and the potential for retrofit," Energ Buildings, vol. 42, pp. 1582-1591, 2010. DOI: $10.1016 /$ j.enbuild.2010.05.004

[12] J. Mentens, D. Raes and M. Hermy, "Green roofs as a tool for solving the rainwater runoff problem in the urbanized 21st century?" Landscape Urban Plan, vol. 77, pp. 217-226, 2006. DOI: 10.1016/j.landurbplan.2005.02.010.

[13] R. Fioretti, A. Palla, L. G. Lanza and P. Principi, "Green roof energy and water related performance in the Mediterranean climate," Build Environ, vol. 45, pp. 1890-1904, 2010.
$10.1016 /$ j.buildenv.2010.03.001.

[14] J. F. Li, O. W. H. Wai, Y. S. Li, J. M. Zhan, Y. A. Ho and J. Li, "Effect of green roof on ambient $\mathrm{CO} 2$ concentration," Build Environ, vol. 45, pp. 2644-2651, 2010. DOI: $10.1016 /$ j.buildenv.2010.05.025.

[15] T. Van Renterghem and D. Botteldooren, "In-situ measurements of sound propagating over extensive green roofs," Build Environ, vol. 46, pp. 729-738, 2011. DOI: $10.1016 /$ j.buildenv.2010.10.006.

[16] S. Schrader and M. Böning, "Soil formation on green roofs and its contribution to urban biodiversity with emphasis on Collembolans," Pedobiologia, vol. 50, pp. 347-356, 2006. DOI: 10.1016/j.pedobi.2006.06.003.

[17] S. Brenneisen, "Space for urban wildlife: designing green roofs as Habitats in Switzerland," Urban Habit, vol. 4, pp. 27-36, 2006. 
[18] C. Feng, Q. Meng and Y. Zhang, "Theoretical and experimental analysis of the energy balance of extensive green roofs," Energ Buildings, vol. 42, pp. 959-965, 2010. DOI: 10.1016/j.enbuild.2009.12.014.

[19] S. Onmura, M. Matsumoto and S. Hokoi, "Study on evaporative cooling effect of roof lawn gardens," Energ Buildings, vol. 33, pp. 653-666, 2001. DOI: 10.1016/S0378-7788(00)00134-1.

[20] N. H. Wong, Y. Chen, C. L. Ong and A. Sia, "Investigation of thermal benefits of rooftop garden in the tropical environment," Build Environ, vol. 38, pp. 261-270, 2003. DOI: 10.1016/S0360-1323(02)00066$\underline{5}$.

[21] A. Teemusk and U. Mander, "Green roof potential to reduce temperatures fluctuations of a roof membrane: a case study from Estonia," Build Environ, vol. 44, pp. 643-650, 2009. DOI: 10.1016/j.buildenv.2008.05.011.

[22] V. Costanzo, G. Evola, L. Marletta and A. Gagliano, "Proper evaluation of the external convective heat transfer for the thermal analysis of cool roofs," Energ Buildings, vol. 77, pp. 467-477, 2014. DOI: $\underline{10.1016 / j . e n b u i l d .2014 .03 .064 .}$

[23] S. Parizzotto and R. Lamberts. "Investigation of green roof thermal performance in temperate climate: A case study of an experimental building in Florianòpolis city, Southern Brazil," Energ Buildings, vol. 43, pp. 17121722, 2011. DOI: 10.1016/j.enbuild.2011.03.014.

[24] D. Kolokotsa, M. Santamouris and S. C. Zerefos. "Green and cool roofs' urban heat island mitigation potential in European climates for office buildings under free floating conditions," Sol Energy, vol. 95, pp. 118-130, 2013. DOI: 10.1016/j.solener.2013.06.001.

[25] E. Eumorfopoulou and D. Aravantinos, "The contribution of a planted roof to the thermal protection of buildings in Greece," Energ Buildings, vol. 27, pp. 29-36, 1998. DOI: 10.1016/S0378-7788(97)00023-6.

[26] A. L. Pisello, C. Piselli and F. Cotana, "Thermalphysics and energy performance of an innovative green roof system: The Cool-Green Roof," Sol Energy, vol. 116, pp. 337-356, 2015. http://dx.doi.org/10.1016/j.solener. 2015.03.049.

[27] R. Kumar and S. C. Kaushik, "Performance evaluation of green roof and shading for thermal protection of buildings," Build Environ, vol. 40, no. 11, pp. 15051511, 2005. DOI: 10.1016/j.buildenv.2004.11.015.

[28] I. Jaffal, S. E. Ouldboukhitine and R. Belarbi, “A comprehensive study of the impact of green roofs on building energy performance," Renew Energ, vol. 43, pp. 157-164, 2012. DOI: 10.1016/j.renene.2011.12.004.

[29] T. Susca, S. R. Gaffin and G.R. Dell'Osso, "Positive effects of vegetation: urban heat island and green roofs," Environ Pollut, vol. 159, pp. 2119-2126, 2011. DOI: $10.1016 / \mathrm{j}$.envpol.2011.03.007.

[30] A. Gagliano, M. Detommaso, F. Nocera, F. Patania and S. Aneli, "The retrofit of existing buildings through the exploitation of the green roofs - A simulation study," Energ Procedia, vol. 62, pp. 52-61, 2014. DOI: $10.1016 /$ j.egypro.2014.12.366.

[31] A. Gagliano, M. Detommaso, F. Nocera and G. Evola, "A multi-criteria methodology for comparing the energy and environmental behavior of cool, green and traditional roofs," Build Environ, vol. 90, pp. 71-81, 2015. DOI: $10.1016 /$ j.buildenv.2015.02.043.

[32] V. Costanzo, G. Evola and L. Marletta. "Energy savings in buildings or UHI mitigation? Comparison between green roofs and cool roofs," Energ Buildings, vol. 114, pp. 247-255, 2016. DOI: 10.1016/j.enbuild.2015.04.053.

[33] P. Bevilacqua, D. Mazzeo, R. Bruno and N. Arcuri, "Experimental investigation of the thermal performances of an extensive green roof in the Mediterranean area," Energ Buildings, vol. 122 pp.6379, 2016. DOI: 10.1016/j.enbuild.2016.03.062.

[34] M. Santamouris, "Heat island research in Europe - the state of the art," Adv Build Energ Res, vol. 1, pp. 23150, 2007. DOI: $10.1080 / 17512549.2007 .9687272$.

[35] DesignBuilder - energy simulation software, version 3, available at http://designbuilder.co.uk.

[36] http://www.moseslab.dieei.unict.it

[37] EnergyPlus 6.0, US DOE, USA, 2010. Available at http://www.energyplus.gov.

[38] A. Gagliano, F. Nocera, F. Patania, A. Moschella, M. Detommaso, G. Evola, "Synergic effects of thermal mass and natural ventilation on the thermal behaviour of traditional massive buildings," Int Jour of Sust Energ, vol. 35, pp. 411-428, 2016. DOI 10.1080/14786451.2014.910517.

[39] C. Bibbiani and A. Pardossi. "Le proprietà fisiche e idrauliche dei substrati di coltivazione". Quaderno Arsia, 2004,http://www.clamerinforma.it/ARSIA/Schede ac qua /Arsia_Capitolo_VI.pdf.

[40] D. J. Sailor, "A green roof model for building energy simulation programs," Energ Buildings, vol. 40, pp. 1466-1478, 2008. DOI: 10.1016/j.enbuild.2008.02.001.

\section{NOMENCLATURE}

$\mathrm{C}_{P}$
$\mathrm{DF}$
$\mathrm{h}$
$\mathrm{H}$
$\mathrm{I}$
$\mathrm{LA}$
$\mathrm{r}$
$\mathrm{r}_{\mathrm{s}}$
$\mathrm{R}$
$\mathrm{s}$
$\mathrm{SM}$
$\mathrm{t}$
$\mathrm{T}$
$\mathrm{TL}$
$\mathrm{U}$

\section{Greek symbols}

$\alpha$

$\varepsilon$

$\theta$

$\lambda$

$\rho$

$\tau$

\section{Subscripts}

f specific heat, $\mathrm{J} \mathrm{kg}^{-1} \mathrm{~K}^{-1}$

decrement factor, -

heat transfer coefficient, $\mathrm{W} \mathrm{m} \mathrm{m}^{-2} \mathrm{~K}^{-1}$

height of the plants, $\mathrm{m}$

solar irradiance, $\mathrm{Wm}^{-2}$

leaf area index, $\mathrm{m}^{2} \mathrm{~m}^{-2}$

short wave reflectance, -

stomatal resistance, $\mathrm{s} \mathrm{m}^{-1}$

thermal resistance, $\mathrm{W} \mathrm{m} \mathrm{m}^{-1} \mathrm{~K}^{-1}$

thickness, $\mathrm{m}$

surface mass, $\mathrm{kg} \mathrm{m}^{-2}$

transmissivity, -

temperature, ${ }^{\circ} \mathrm{C}$

time lag, $\mathrm{h}$

thermal transmittance, $\mathrm{W} \mathrm{m}^{-2} \mathrm{~K}^{-1}$

absorptance, -

thermal emissivity, moisture content, $\mathrm{m}^{3} \mathrm{~m}^{-3}$ thermal conductivity, $\mathrm{W} \mathrm{m}^{-1} \mathrm{~K}^{-1}$ density, $\mathrm{kg} \mathrm{m}^{-3}$

time, $\mathrm{h}$

foliage 


$\begin{array}{llll}\mathrm{g} & \text { ground } & \mathrm{o} & \text { outdoor } \\ \text { in } & \text { initial } & \text { si } & \text { inner surface } \\ \max & \text { maximum } & \text { so } & \text { outer surface } \\ \min & \text { minimum } & \text { sat } & \text { saturation }\end{array}$

solar-air 